\title{
Analisis Pengaruh Sifat Prokrastinasi pada Siswa SMA hingga Jenjang Universitas di Indonesia
}

\author{
Muhammad Rafi Kuntjoro \\ Jurusan Teknologi Pendidikan, Fakultas Ilmu Pendidikan, Universitas Negeri Malang \\ Email: mrafikuntjoro.1801216@students.um.ac.id
}

\begin{abstract}
Abstrak
Tujuan dari artikel telaah ini adalah untuk mengetahui pengaruh sifat prokrastinasi atau bisa disebut sebagai penundaan dalam artian menunda belajar atau mengerjakan tugas rumah siswa berpengaruh terhadap proses berlangsungnya kegiatan dalam pembelajaran. Pengumpulan data dilakukan dengan menelaah jurnal nasional maupun internasional yang berhubungan dengan topik yang dibahas. Dengan mengetahui dampak dan penyebab dari sifat prokrastinasi ini maka siswa dapat lebih efisien dalam melakukan manajemen waktu.
\end{abstract}

Kata kunci: Siswa, Prokrastinasi, Sekolah Menengah Atas

\section{Analysis of the Effects of Procrastination on High School Students to University Levels in Indonesia}

\author{
Muhammad Rafi Kuntjoro \\ Department of Educational Technology, Faculty of Education, Universitas Negeri Malang \\ Email: mrafikuntjoro.1801216@students.um.ac.id
}

\begin{abstract}
The purpose of this review article is to find out the influence of the nature of procrastination or can be called a delay in the sense of delaying learning or doing student homework affect the process of ongoing learning activities. Data collection is done by examining national and international journals that relate to the topics discussed. By knowing the impact and causes of the nature of this procrastination, students can be more efficient in managing time.
\end{abstract}

Keywords: Students, Procrastination, High School 


\section{PENDAHULUAN}

Artikel telaah ini berjudul "analisis sistem prokrastinasi pada siswa SMA di Indonesia dalam kegiatan belajar". Belajar merupakan tugas utama seorang siswa, namun tidak semua siswa memiliki pengelolaan belajar yang baik. Pengelolaan belajar dapat memengaruhi prestasi atau hasil belajar siswa. Hasil belajar sendiri diartikan sebagai perubahan tingkah laku siswa setelah melalui proses belajar mengajar (Muflihah, S \& Lepith, H, 2019:49). Masalah pengelolaan belajar yang sering dialami oleh siswa sekolah ialah penundaan dalam mengerjakan tugas. Perilaku menunda-nunda tugas akademik disebut dengan prokrastinasi akademik. Prokrastinasi menurut Ferrari (Ghufron, 2003:17) dapat dipandang dari berbagai batasan tertentu, diantaranya ialah prokrastinasi hanya sebagai perilaku penundaan, prokrastinasi sebagai suatu kebiasaan atau pola perilaku dan prokrastinasi sebagai suatu trait kepribadian.

Secara umum faktor-faktor yang mempengaruhi perilaku menunda atau prokarastinasi akademik dapat dikategorikan menjadi dua, yaitu faktor eksternal dan faktor internal. Faktor eksternal yaitu faktor yang terdapat dari luar diri individu meliputi: gaya pengasuhan orang tua dan kondisi lingkungan. Sedangkan faktor internal yaitu faktor yang ada pada diri individu yang melakukan prokrastinasi, yaitu unsur struktur kepribadian. Menurut Bandura dalam Alwisol (2009:284) struktur kepribadian saling determinis menempatkan semua hal saling berinteraksi, pusatnya ialah sistem self yang mengacu ke struktur kognitif kemudian memberi pedoman mekanisme dan seperangkat fungsi-fungsi persepsi, evaluasi dan pengaturan tingkah laku. Sehingga jika fungsi-fungsi persepsi dan evaluasi baik, maka tingkah laku yang nampak, khususnya prokrastinasi akademik tidak akan terjadi.

Konsep diri akademik adalah gambaran individu terhadap kemampuan akademiknya, yang meliputi kemampuan dalam mengikuti kegiatan pembelajaran, kemampuan meraih prestasi di bidang akademik, serta aktivitas di sekolah atau di kelas yang berkaitan dengan persepsi, pikiran, perasaan dan penilaian seseorang terhadap kemampuan akademiknya (Atmasari, 2009). Efikasi diri akademik diartikan sebagai keyakinan individu terhadap kemampuannya, semakin individu yakin terhadap kemampuannya, maka semakin besar usaha yang dilakukannya dan makin aktif ia karena ia yakin kemampuannya tersebut dapat membantu dalam mengerjakan suatu tugas dan membantu menghadapi hambatan/rintangan untuk mencapai prestasi 
akademik yang tinggi. Sedangkan self-esteem ialah penilaian mengenai individu mengenai hal-hal yang berkaitan dengan dirinya, baik dari pengalaman yang dialaminya maupun pengalaman yang dipelajari dari orang lain berkaitan pencapaian prestasi akademik. Menurut Worchel dalam Dayakisni (2009) selfesteem merupakan komponen evaluatif dari konsep diri, yang terdiri dari evaluasi positif dan negatif tentang diri sendiri.

Hasil penelitian yang dilakukan oleh Lampert (2007) mengenai hubungan antara self-efficacy akademik, konsep diri akademik dan prestasi akademik menunjukkan bahwa self-efficacy akademik adalah prediktor yang signifikan yang dapat digunakan dalam memprediksi prestasi akademik dibandingkan dengan konsep diri akademik. Sementara prestasi akademik individu dipengaruhi juga oleh kebiasaan menunda atau tidak tugas-tugas akademik seperti yang telah disampaikan sebelumnya. Erma (2013) dalam penelitiannya menunjukkan bahwa memang terdapat hubungan negatif yang sangat signifikan antara harga diri dengan prokrastinasi akademik mahasiswa, artinya semakin tinggi harga diri semakin rendah prokrastinasi akademik dan berlaku sebaliknya. Penelitian dengan variabel lain juga menemukan bahwa terdapat hubungan kebalikan antara tingkat prokrastinasi dan self-efficacy. Dengan kata lain, tingkat prokrastinasi akademik bertambah jika self-efficacy menurun (Martyana, 2013).

Ketika peserta didik tidak dapat memanfaatkan waktu belajar dengan baik, sering mengulur waktu dengan melakukan kegiatan yang tidak bermanfaat sehingga waktu terbuang dengan sia-sia. Tugas akademik terbengkalai dan penyelesaian tugas tidak maksimal pada akhinya menjadikan kegagalan atau terhambatnya seorang peserta didik meraih kesuksesan. Kegagalan atau kesuksesan individu sebenarnya bukan karena faktor intelegensi semata namun salah satunya adalah kebiasaan melakukan penundaan terutama dalam penyelesaian tugas akademik yang disebut dengan prokrastinasi akademik. (Savira F dan Suharsono Y, 2013:66).

Solomon \& Rothblum (1984: 503) mengatakan "Procrastination, the act of needlessly delaying tasks to the point of experiencing subjective discomfort, is an alltoo-familiar problem”. Pernyataan ini menjelaskan bahwa suatu penundaan dikatakan sebagai prokrastinasi apabila penundaan itu dilakukan pada tugas yang penting, dilakukan berulang-ulang secara sengaja, menimbulkan perasaan tidak nyaman, serta secara subyektif dirasakan oleh seorang prokrastinator. Dalam kaitannya dengan 
lingkup akademik, prokrastinasi dijelaskan sebagai perilaku menunda tugas-tugas akademis (seperti: mengerjakan pekerjaan rumah (PR), mempersiapkan diri untuk ujian, atau mengerjakan tugas makalah) sampai batas akhir waktu yang tersedia.

Prokrastinasi akademik merupakan tindakan yang tidak baik jika terus dibiarkan. Prokrastinasi adalah menunda dengan sengaja kegiatan yang diinginkan walaupun individu mengetahui bahwa perilaku penundaanya tersebut dapat menghasilkan dampak buruk. Sirois (2004: 269-286) mengatakan bahwa "A variety of negative outcomes have been linked to procrastination including poor academic performance, higher stress, increased illness, and higher anxiety when recalling procrastinating behavior." Dampak negatif dari prokrastinasi jelas tidak menguntungkan bagi siapapun, jika performa akademik rendah bisa jadi seseorang tidak naik kelas. Jika memiliki stress tinggi, bagaimana seseorang dapat menjalani kehidupan sehari- hari dengan wajar. Mengakibatkan penyakit, jelas sekali merupakan hal buruk. Dan memiliki kecemasan yang tinggi, kehidupan tidak akan benar-benar dijalani dengan kebahagiaan.

Permasalahan prokrastinasi akademik yang dimiliki oleh siswa SMA ini tidak hanya menjadi tanggung jawab guru bidang studi maupun wali kelas saja, akan tetapi juga menjadi tanggung jawab guru BK (konselor). Bimbingan dan Konseling memiliki tanggung jawab untuk memberikan pelayanan agar siswa memperoleh kesejahteraan lahir dan batin dalam proses pendidikan yang ditempuh. BK mempunyai posisi kunci di dalam kemajuan atau kemunduran pendidikan, tidak hanya terbatas pada bimbingan yang bersifat akademik tetapi juga pribadi, sosial, dan karier. Wardati \& Jauhar (2011:53) berpendapat bahwa dengan adanya BK di sekolah maka integrasi dari seluruh potensi ini dapat dimunculkan sehingga keseluruhan aspek yang muncul bukan hanya kognitif atau akademis saja tetapi juga seluruh komponen dirinya baik itu kepribadian, hubungan sosial serta memiliki nilai-nilai yang dapat dijadikan pegangan.

\section{KAJIAN LITERATUR}

Pada saat mencari kata kunci prokrasinasi, pertama saya mencari kepopuleran salah satu kata kunci yaitu prokrasinasi di google trend. Disana mendapatkan hasil kepopuleran pencarian kata kunci prokarsinasi. Maka dari itu akan disajikan data tersebut melalui tabel di bawah ini. 
Sekolah menengah atas (SMA) dikatakan sebagai langkah lanjutan setelah lulus sekolah menengah pertama (SMP). Dalam perjalanan pendidikan negara Indonesia, SMA merupakan tempat siswa untuk lebih dewasa. Maksud dari lebih dewasa yaitu tanggung jawab yang diemban oleh siswa SMA mulai bertambah. Selain itu, perkembangannya harus diseimbangi dengan perkembangan emosional dan mental.

Siswa SMA dalam proses belajar diharapkan dapat lebih efektif dalam pengerjaan maupun pengumpulan tugas. Namun dalam hasil lapangan masih banyak siswa yang menerapkan Sistem Kebut Semalam. Berdasarkan penelitian terdahulu ditemukan data bahwa siswa masih menggunakan "Sistem Kebut Semalam (SKS)" untuk belajar, mengerjakan tugas satu hari sebelum dikumpulkan, mengerjakan tugas di sekolah sebelum bel masuk dibunyikan, mengobrol saat mengerjakan tugas dan keterlambatan mengumpulkan tugas(Alvira, 2014; Khotimah et al., 2016).

Fenomena SKS atau Sistem Kebut Semalam masih menjadi primadona dalam cara belajar siswa. Disiplin belajar dapat tumbuh dan dibina melalui latihan, pendidikan atau penanaman kebiasaan yang harus dimulai sejak dalam lingkungan keluarga, mulai pada masa kanak-kanak dan terus tumbuh berkembang. Dengan disiplin belajar seharusnya siswa tidak terlalu berat untuk menghadapi ujian sehingga mendapatkan hasil yang maksimal. Namun beberapa siswa masih belum bisa menerapkan disiplin belajar(Istidiana, 2018).

Secara umum faktor-faktor yang mempengaruhi perilaku menunda atau prokarastinasi akademik dapat dikategorikan menjadi dua, yaitu faktor eksternal dan faktor internal. Faktor eksternal yaitu faktor yang terdapat dari luar diri individu meliputi: gaya pengasuhan orang tua dan kondisi lingkungan. Sedangkan faktor internal yaitu faktor yang ada pada diri individu yang melakukan prokrastinasi, yaitu unsur struktur kepribadian.

Selain itu banyak peserta didik yang belajarnya hanya SKS (sistem kebut semalam), sehingga hasil yang mereka peroleh kurang maksimal (Legi et al., 2016). Hal tersebut juga dipengaruhi oleh efikasi diri peserta didik yang rendah karena dirinya tidak yakin atas kemampuannya dalam mengerjakan tugas tersebut, akhirnya menundanunda dalam mengerjakan tugas dan terkadang cenderung untuk menyontek teman (Nurhasanah et al., 2018) . Menurut dunia psikologis, perilaku menunda-nunda mengerjakan tugas ini disebut dengan istilah prokrastinasi. Sementara itu dalam dunia 
psikologi pendidikan, perilaku menunda-nunda mengerjakan tugas disebut dengan istilah prokrastinasi akademik (Kurniawan, 2017). Banyak siswa SMA yang masih belum memiliki kemampuan dalam mengelola waktu, di antaranya yaitu jadwal belajar yang tidak menentu, menggunakan Sistem Kebut Semalam (SKS) dalam menghadapi pembelajaran di kelas, serta terlambat dalam mengumpulkan tugas. Kebanyakan siswa melakukan aktivitas belajar secara santai, hanya tampak sibuk menjelang waktu ujian dan belajar secara "SKS" (sistem kebut semalam)(SULASTRI \& FIVENTI, n.d.). Pada waktu-waktu jam yang kosong umumnya mereka berkumpul dan mengobrol dengan teman-temannya dikelas dan tidak terlihat bersemangat untuk membaca buku sebanyakbanyaknya dan berusaha memperluas pengetahuan. Perilaku-perilaku diatas tentu tidak efektif dan menghambat keberhasilan siswa dalam melaksanakan pembelajaran di sekolah dan menyebabkan rendahnya prestasi belajar siswa (Rahayu et al., 2017). Hal ini sejalan juga dengan penelitian yang dilakukan Sari (2019) yang menyatakan bahwa Tinggi rendahnya motivasi belajar siswa berpengaruh terhadap prestasi belajar siswa.

Bisa dibilang bahwa sistem kebut semalam merupakan taktik yang paling sering digunakan oleh peserta didik,dimana taktik ini cenderung memaksa peserta didik untuk menyelesaikan tugas semalam sebelum tugas tersebut dikumpulkan (Artikadyar, 2017). Siswa lebih sering menghafal materi bukannya memahami materi, sehingga mereka hanya ingat pada saat ulangan saja, setelah ulangan kebanyakan apa yang telah dihafal lupa begitu saja. Selain itu, pada saat pembelajaran jika guru memberikan tugas atau PR kebanyakan siswa tidak mengerjakan sendiri tugas/PR tersebut, mereka lebih sering mencontek pekerjaan milik temannya. Kebiasaan belajar yang kurang baik ini karena siswa banyak siswa yang lebih memprioritaskan bermain dan berkumpul bersama teman dibandingkan dengan belajar. Waktu mereka lebih banyak dihabiskan untuk bermain dan berkumpul dibandingkan belajar (Paramita et al., 2013).

Adapun cara yang dibuat oleh guru untuk mengatasi siswa yang sering menggunakan sistem kebut semalam (SKS). Evaluasi yang dilakukan di School of Human dalam aspek kognitif diberikan dalam bentuk HOTS atau High Order Thinking Skill agar siswa bisa berlatih berfikir tingkat tinggi, namun dengan sistem open book agar siswa bisa melatih berfikir kritis, analitis dan kreatif dalam menggali informasi untuk jawaban soal tersebut. system ujian open book siswa diberi peluang untuk tidak 
mengandalkan pada pengetahuan yang diingat sesaat sebagai hasil belajar dengan cara sistem kebut semalam (SKS) (Hakim et al., 2019).

Namun masih banyak siswa mengaku lebih senang menggunakan sistem kebut semalam (SKS) ini. Padahal ada mata pelajaran yang tidak semua bersifat hapalan seperti matematika yang membutuhkan penerapan. Oleh karena itu masih banyak siswa hanya mengulang materi pelajaran pada satu malam sebelum masuk ke kelas dan mulai masuk dalam pembelajaran. Padahal proses belajar matematika tidak cukup hanya diulang satu kali menjelang tes hasil belajar (Saadah, 2017).

Sistem kebut semalam (SKS) ini juga dipengaruhi oleh meningkatnya kompetisi dan perubahan gaya hidup, siswa telah membalikkan jam tidur mereka saat ini, karena mereka lebih suka belajar larut malam daripada bangun pagi-pagi. Ini tidak hanya mengganggu siklus tidur mereka tetapi juga memiliki efek buruk pada mata dan tubuh (Gillen-O’Neel et al., 2013). Menurut data dari (Matar Boumosleh \& Jaalouk, 2017) Tingkat prevalensi perilaku kompulsif terkait smartphone, penurunan fungsi, toleransi dan gejala penarikan adalah substansial. 35,9\% dari sampel kami melaporkan bahwa mereka merasa lelah pada siang hari karena penggunaan smartphone larut malam, $38,1 \%$ dari mereka mengakui bahwa kualitas tidur mereka menurun, dan 35,8\% mengakui bahwa mereka tidur kurang dari empat jam karena penggunaan smartphone lebih dari satu kali. Dengan kata lain banyak siswa yang menggunakan hp larut malam untuk mencari materi yang akan dipelajari esok hari.

Sistem kebut semalam ini memiliki dampak yang tidak baik bagi siswa SMA. Namun hal ini akan menjadi hal biasa bila siswa sudah menjadi mahasiswa dikarenakan tanggung jawab dan beban studi yang jauh lebih berat daripada saat SMA. Hal itu menjadi alasan konkrit atas perbedaan antara siswa SMA dan mahasiswa (Milsted, 2010).

Pada dasarnya sistem kebut semalam lebih mengarah pada penundaan. Penundaaan disini memiliki maksud Penundaan, sebagai perilaku menunda yang tidak perlu memulai atau menyelesaikan tugas apa pun, menghasilkan emosi yang tidak sehat seperti kecemasan, depresi, rasa malu dan menyalahkan, dan itu adalah masalah umum di kalangan siswa (Balkis, 2013). Namun Penundaan dianggap sebagai salah satu masalah paling serius dalam kehidupan sehari-hari dan latar pendidikan di masyarakat modern. Didefinisikan sebagai penundaan penyelesaian tugas yang biasanya 
mengakibatkan ketidakbahagiaan atau ketidaknyamanan subyektif. Secara khusus, prokrastinasi akademik adalah perilaku yang meresap dan berpotensi maladaptif (Azar, 2013).

Ada hubungan negatif yang signifikan antara efikasi diri akademik dan akademik penundaan. Siswa yang memiliki tingkat prokrastinasi akademik yang tinggi juga memiliki akademik yang lebih rendah Efikasi Diri. Tingkat prokrastinasi akademik menghasilkan negatif signifikan secara statistik hubungan dengan prestasi akademik. Siswa yang memiliki tingkat prokrastinasi akademik yang lebih tinggi tidak berkinerja baik di kelas akhir kursus. Keterampilan akademik sebelum, diprediksi oleh Tes Penempatan Keterampilan Menulis KOMPAS, menghasilkan hubungan yang signifikan secara statistik dengan prestasi akademik. Siswa dengan skor COMPASS yang lebih tinggi mencapai akhir kursus yang lebih tinggi nilainya(Jackson, 2012).

Siswa dan pria yang lebih tua memiliki tingkat prokrastinasi akademik yang lebih tinggi. Siswa kemungkinan besar menunda-nunda belajar untuk ujian, tugas membaca mingguan, dan menyelesaikan tugas menulis. Keengganan tugas adalah alasan terpenting yang diberikan siswa menunda-nunda. Siswa dan pria yang lebih muda lebih banyak menolak tugas. Ketakutan akan faktor kegagalan adalah tidak sepenting keengganan tugas sebagai penjelasan untuk prokrastinasi akademik(Kim et al., 2017).

Salah satu perilaku pengaturan diri yang telah dipelajari secara luas dalam literatur adalah akademik prokrastinasi dan pengaruhnya terhadap prestasi siswa. Siswa yang menunda-nunda mungkin memilikinya pikiran atau perilaku yang menghambat kemampuan mereka untuk mengatur diri sendiri, misalnya, perkiraan salah waktu yang dibutuhkan untuk menyelesaikan tugas belajar dan efikasi diri yang rendah. Prokrastinasi akademik adalah konstruksi multidimensi dengan perilaku, komponen kognitif, dan afektif. Prokrastinasi akademik pada mahasiswa menunjukkan kurangnya kontrol diri dan, ketika dikombinasikan dengan self-efficacy yang lebih rendah untuk akademisi, dapat menyebabkan prestasi akademik yang lebih rendah(Haghani, 2014).

Prokrastinasi akademik cukup umum di kalangan mahasiswa dan dapat berdampak negatif terhadap prestasi akademik. Prokrastinasi akademik didefinisikan sebagai kegagalan untuk melakukan kegiatan akademik dalam jangka waktu yang diinginkan atau menunda sampai aktivitas menit terakhir yang perlu diselesaikan. Prokrastinasi akademik didefinisikan sebagai kegagalan untuk melakukan kegiatan 
akademik dalam jangka waktu yang diinginkan atau menunda sampai aktivitas menit terakhir yang perlu diselesaikan(Klassen et al., 2010).

Penelitian ini menguji hubungan antara keyakinan self-efficacy akademik, akademik menunda-nunda, dan keterampilan akademis sebelumnya untuk siswa mengambil pendidikan perkembangan kursus. Pemahaman tentang hubungan yang diajukan dalam penelitian ini dapat membantu guru, konselor, dan penasihat lebih memahami aspek perilaku mahasiswa. Interaksi dan hubungan antara variabel-variabel seperti prokrastinasi akademik, self-efficacy akademik, dan keterampilan akademik sebelumnya membantu mengidentifikasi faktor-faktor penting yang berkontribusi terhadap keberhasilan siswa mengambil kursus pengembangan. Ini, pada gilirannya, akan membantu dalam pengembangan akademik strategi untuk mengurangi kemungkinan bahwa siswa akan gagal ketika terdaftar dalam pengembangan kursus (Seo, 2012).

Prokrastinasi akademik sering terjadi di kalangan siswa dan mungkin memiliki dampak negatif pada prestasi akademik. Prokrastinasi akademik didefinisikan sebagai gagal melakukan kegiatan akademik dalam jangka waktu yang diinginkan atau menunda sampai kegiatan menit terakhir seseorang perlu menyelesaikan(Kennedy \& Tuckman, 2013). Dalam penelitian ini, kompleks perilaku prokrastinasi siswa diperiksa melalui teori kognitif sosial dan pengaturan diri. Teori kognitif sosial mempertimbangkan faktor motivasi dan kognitif bersama-sama untuk memahami perilaku siswa dalam konteks akademik. Siswa yang suka menunda adalah tidak belajar mandiri karena mereka gagal untuk memantau dan mengontrol aspek-aspek penting dari perilaku belajar mereka (Glick \& Orsillo, 2015). Ciri-ciri penting pengaturan diri dalam lingkungan belajar termasuk pengarahan tujuan, manajemen waktu akademik, praktik yang bermakna dan terarah, penggunaan strategi kognitif dan metakognitif yang tepat, dan rasa kemanjuran diri (Grunschel et al., 2013). Studi ini mendefinisikan dan mengeksplorasi hubungan prokrastinasi akademik dan self-efficacy akademik pada tingkat pencapaian siswa yang terdaftar dalam kursus pengembangan. Prokrastinasi dan prokrastinasi akademik sifat diukur dengan Skala Penilaian Penundaan-Siswa (Seo, 2012)(Seo, 2011).

Pendidik, penasihat, penasihat, dan psikolog semuanya berkontribusi pada penelitian dan literatur tentang perilaku siswa seperti prokrastinasi akademik. Mereka ditantang di dalam bidang praktik mereka untuk menerapkan pendekatan intervensi 
yang sehat untuk perilaku kompleks ini (Özer \& Saçkes, 2011). Pengetahuan dari penelitian yang dilakukan sejak 1980-an telah dikonfirmasi bahwa komponen perilaku, kognitif, dan emosional, berkontribusi pada penundaan siswa kecenderungan (Balkis \& Duru, 2016). Pendidik terus menafsirkan berbagai penyebab prokrastinasi akademik dan menerapkan teknik intervensi khusus seperti konseling dan lokakarya untuk membantu siswa mencapai kesuksesan. Karena ada banyak penyebab penundaan akademik, pendidik harus melakukannya menyadari faktor utama dan mengakui pendekatan yang berbeda untuk mendukung upaya siswa perubahan (Iskender, 2011).

Sampai saat ini, penelitian belum meneliti hubungan prokrastinasi akademik kecenderungan dan keyakinan self-efficacy akademik untuk siswa yang mengambil kursus pengembangan. Intervensi terkoordinasi untuk siswa dalam pendidikan perkembangan secara historis berfokus pada tiga bidang: (a) kurikulum restrukturisasi, (b) mengembangkan struktur kelembagaan baru, dan (c) menggunakan strategi atau teknologi pengajaran khusus yang dirancang untuk meningkatkan pembelajaran (Klassen et al., 2010). Tren dalam pendidikan memaksa perguruan tinggi untuk melihat lebih dekat pendidikan perkembangan termasuk (a) sejumlah besar siswa nontradisional masukperguruan tinggi, (b) institusi yang menyuarakan masalah moral dan keuangan tentang retensi, dan (c) legislator dan wajib pajak yang membutuhkan tingkat akuntabilitas yang lebih tinggi (Karatas, 2015). Termasuk dalam pemeriksaan ulang pendidikan pembangunan harus dukungan akademik program dan intervensi yang ditawarkan oleh pendidik, penasihat, dan konselor yang menyaksikan secara spesifik perilaku negatif siswa seperti menunda-nunda. Temuan dari penelitian ini dapat berkontribusi untuk pemahaman yang lebih mendalam tentang siswa dalam kursus pendidikan perkembangan dengan memberikan wawasan yang bermanfaat untuk mengembangkan strategi intervensi bertarget yang dirancang untuk mengurangi perilaku menunda-nunda, mengatur belajar, dan meningkatkan prestasi akademik.

Dalam kurun waktu 10 tahun, korelasinya 0,77, indikasi bahwa penundaan cukup stabil untuk menjadi suatu sifat. Akademik prokrastinasi terjadi karena faktor perbedaan individu dan paling sering terkait dengan Faktor hati nurani dalam model kepribadian Lima Besar, yang meliputi faktor Extraversion, Agreeableness, Nurani, Neurotisme, dan Keterbukaan. Faktor Kesadaran meliputi aspek ketertiban, kepatuhan, disiplin diri, pencapaian prestasi, kompetensi, dan musyawarah. Penyebab dan korelasi dari 
penundaan telah dipelajari secara luas. Steel melaporkan dalam meta-analisis bahwa penyebab dan korelasi untuk penundaan dibagi menjadi empat bidang: karakteristik tugas, perbedaan individu, hasil, dan demografi. Penelitian melihat karakteristik tugas menguji penundaan dengan pemahaman bahwa orang yang menunda-nunda secara sukarela memilih satu perilaku atau tugas daripada yang lain. Faktor yang terkait dengan tugas karakteristik prokrastinasi (keengganan tugas) termasuk waktu pemberian dan hukuman.

Seiring waktu, ide-ide tentang prokrastinasi akademik telah berkembang untuk memasukkan kognitif komponen dan penjelasan perilaku kognitif. Penjelasan pertama tentang penundaan dari perspektif kognitif-perilaku datang dari Ellis dan Knaus (1977), yang terkait kecenderungan menunda-nunda untuk ketakutan irasional dan kritik diri (Ferrari et al., 1995). Kognisi yang berhubungan dengan perilaku prokrastinasi akademik pada siswa termasuk perkiraan waktu yang salah diperlukan untuk menyelesaikan tugas belajar, kesalahpahaman tentang pengaruh diskon pada studi motivasi, dan self-efficacy yang rendah. Perilaku ini mungkin bertanggung jawab untuk berkontribusi melanjutkan penundaan. Konselor yang mengadopsi pandangan ini percaya bahwa intervensi ditujukan mengubah kognisi siswa dapat mematahkan efek penguatan ini (Schouwenburg et al., 2004). Sebagian besar metode intervensi prokrastinasi akademik yang digunakan di perguruan tinggi saat ini memiliki dasar dalam psikoterapi dan mengandalkan perspektif kognitif-perilaku.

\section{KESIMPULAN}

Berdasarkan hasil penelitian dapat ditarik simpulan bahwa: (1) terdapat hubungan negatif antara konsep diri akademik dengan prokrastinasi akademik pada siswa SMA Negeri di Indonesia. Artinya, semakin tinggi tingkat konsep diri akademik siswa maka semakin rendah prokrastinasi akademik siswa, begitu sebaliknya, (2) terdapat hubungan negatif antara efikasi diri akademik dengan prokrastinasi akademik pada siswa SMA Negeri di Indonesia. Artinya, semakin tinggi tingkat efikasi diri akademik siswa maka semakin rendah prokrastinasi akademik siswa, begitu sebaliknya, (3) terdapat hubungan negatif antara self-esteem dengan prokrastinasi akademik pada siswa SMA Negeri di Indonesia. Artinya, semakin tinggi tingkat selfesteem siswa maka semakin rendah prokrastinasi akademik siswa, begitu sebaliknya, (4) konsep diri akademik, efikasi diri 
akademik, self-esteem secara serentak (simultan) berpengaruh negatif terhadap perubahan prokrastinasi akademik, dari data analisis diantara ketiga variabel tersebut yang paling besar mempengaruhi prokrastinasi akademik ialah self-esteem.

\section{DAFTAR REFERENSI}

Alvira, M. (2014). Keefektifan teknik self management untuk mereduksi prokrastinasi akademik siswa SMP. Universitas Negeri Malang.

Artikadyar, N. (2017). Makna tugas menurut peserta didik (Suatu kajian penelitian mengenai tugas menurut peserta didik SMA Batik 1 Surakarta). SOSIALITAS; Jurnal Ilmiah Pend. Sos Ant, 8(1).

Azar, F. S. (2013). Self-efficacy, achievement motivation and academic procrastination as predictors of academic achievement in pre-college students. Proceeding of the Global Summit on Education, 173178.

Balkis, M. (2013). Academic procrastination, academic life satisfaction and academic achievement: the mediation role of rational beliefs about studying. Journal of Cognitive \& Behavioral Psychotherapies, 13(1).

Balkis, M., \& Duru, E. (2016). Procrastination, self-regulation failure, academic life satisfaction, and affective well-being: underregulation or misregulation form. European Journal of Psychology of Education, 31(3), 439-459.

Gillen-O'Neel, C., Huynh, V. W., \& Fuligni, A. J. (2013). To study or to sleep? The academic costs of extra studying at the expense of sleep. Child Development, 84(1), 133-142.

Glick, D. M., \& Orsillo, S. M. (2015). An investigation of the efficacy of acceptance-based behavioral therapy for academic procrastination. Journal of Experimental Psychology: General, 144(2), 400.

Grunschel, C., Patrzek, J., \& Fries, S. (2013). Exploring reasons and consequences of academic procrastination: An interview study. European Journal of Psychology of Education, 28(3), 841-861.

Haghani, H. (2014). The relationship between academic procrastination, academic achievement, and selfefficacy in nursing students of Tehran University of Medical Sciences. Iranian Journal of Medical Education, 14(1), 32-40.

Hakim, A. A., Lathifah, S. S., \& Kurniasih, S. (2019). Implementasi pembelajaran biologi berbasis multiple intellegence di SMA Inkusi School of Human Jatisampurna-Bekasi. PEDAGONAL| JURNAL ILMIAH PENDIDIKAN, 3(2), 56-69.

Iskender, M. (2011). The influence of self-compassion on academic procrastination and dysfunctional attitudes. Educational Research and Reviews, 6(2), 230.

Istidiana, L. F. (2018). Pengaruh pendidikan formal orang tua dan disiplin belajar terhadap hasil belajar ekonomi siswa kelas xi ipsSMA Negeri 1 Bantar Bolang tahun 2016/2017. Jurnal Pendidikan Dan Ekonomi, 7(3), 279-287.

Jackson, D. M. H. (2012). Role of academic procrastination, academic self-efficacy beliefs, and prior academic skills on course outcomes for college students in developmental education. University of Georgia.

Karatas, H. (2015). Correlation among academic procrastination, personality traits, and academic achievement. Anthropologist, 20(1), 2.

Kennedy, G. J., \& Tuckman, B. W. (2013). An exploration into the influence of academic and social values, procrastination, and perceived school belongingness on academic performance. Social Psychology of Education, 16(3), 435-470.

Khotimah, R. H., Radjah, C. L., \& Handarini, D. M. (2016). Hubungan antara konsep diri akademik, efikasi diri akademik, harga diri dan prokrastinasi akademik pada siswa SMP Negeri di kota Malang. Jurnal Kajian Bimbingan Dan Konseling, 1(2), 60-67.

Kim, S., Fernandez, S., \& Terrier, L. (2017). Procrastination, personality traits, and academic performance: When active and passive procrastination tell a different story. Personality and Individual Differences, 108, 154-157. 
Klassen, R. M., Ang, R. P., Chong, W. H., Krawchuk, L. L., Huan, V. S., Wong, I. Y. F., \& Yeo, L. S. (2010). Academic procrastination in two settings: Motivation correlates, behavioral patterns, and negative impact of procrastination in Canada and Singapore. Applied Psychology, 59(3), 361-379.

Kurniawan, A. (2017). Hubungan antara minat belajar sejarah dengan prokrasinasi akademikpada mata pelajaran sejarah siswa kelas xi SMA Negeri 1 Ngimbang. Avatara, 5(1).

Legi, W. K., Asrowi, A., \& Djannah, W. (2016). Modul Bimbingan Belajar untuk Mereduksi Perilaku Prokrastinasi Akademik Peserta Didik SMP. Consilium: Jurnal Program Studi Bimbingan Dan Konseling, 4(2).

Matar Boumosleh, J., \& Jaalouk, D. (2017). Depression, anxiety, and smartphone addiction in university students-A cross sectional study. PLoS One, 12(8).

Milsted, B. (2010). A study of the impact of late night programming on student involvement at Rowan University.

Muflihah, S \& Lepith, H. (2019). Penerapan Pendekatan Contextual Teaching and Learning dalam Meningkatkan Hasil Belajar Matematika pada Materi Luas dan Keliling Bangun Datar. Indonesian Journal of Instructional Media and Model, 1(1), 35-45.

Nurhasanah, N., Purwati, P., \& Ahmad, H. (2018). Pengaruh Sistem Seleksi Masuk Perguruan Tinggi Terhadap Indeks Prestasi Mahasiswa Jurusan Pendidikan Matematika Universitas Papua (UNIPA). Prosiding, 3(1).

Özer, B. U., \& Saçkes, M. (2011). Effects of academic procrastination on college students' life satisfaction. Procedia Social and Behavioral Sciences, 12(1), 512-519.

Paramita, E., Zakso, A., \& Ulfah, M. (2013). Lingkungan sosial budaya sekolah (Pengaruh pada pembelajaran sosiologi di SMA Islamiyah Pontianak). Jurnal Pendidikan Dan Pembelajaran Khatulistiwa, 2(3).

Rahayu, R., Yusmansyah, Y., \& Utaminingsih, D. (2017). Hubungan Antara Regulasi Diri Dengan Prestasi Belajar Pada Siswa Kelas X. ALIBKIN (Jurnal Bimbingan Konseling), 5(5).

Saadah, F. N. (2017). Analisis persiapan siswa kelas xi ips SMA Negeri 1 Cangkringan dalam menghadapi tes hasil belajar pelajaran matematika. Jurnal Pendidikan Matematika-S1, 6(2), 55-66.

Sari, A. Y. (2019). Meningkatkan Motivasi dan Prestasi Belajar Matematika melalui Model Pembelajaran Think-Pair-Share. Indonesian Journal of Instructional Media and Model, 1(1),1-9.

Seo, E. H. (2011). The relationships among procrastination, flow, and academic achievement. Social hasil belaBehavior and Personality: An International Journal, 39(2), 209-217.

Seo, E. H. (2012). Cramming, active procrastination, and academic achievement. Social Behavior and Personality: An International Journal, 40(8), 1333-1340.

SUlASTRI, S., \& FIVENTI, A. D. (n.d.). Pengaruh Kecemasan, Motivasi Belajar, dan Disiplin Belajar Siswa Dalam Menghadapi Ujian Nasional Terhadap Hasil Ujian Nasional Pada Siswa Kelas XII. 